The University of Maine

DigitalCommons@UMaine

Social Justice: Diversity, Equity, \& Inclusion

Special Collections

$11-15-2018$

\title{
Transgender Day of Remembrance
}

Wilde Stein: Queer Straight Alliance

Follow this and additional works at: https://digitalcommons.library.umaine.edu/social_justice

Part of the Feminist, Gender, and Sexuality Studies Commons, Higher Education Commons, and the United States History Commons

\section{Repository Citation}

Wilde Stein: Queer Straight Alliance, "Transgender Day of Remembrance" (2018). Social Justice: Diversity, Equity, \& Inclusion. 424.

https://digitalcommons.library.umaine.edu/social_justice/424

This Image is brought to you for free and open access by DigitalCommons@UMaine. It has been accepted for inclusion in Social Justice: Diversity, Equity, \& Inclusion by an authorized administrator of

DigitalCommons@UMaine. For more information, please contact um.library.technical.services@maine.edu. 


\section{Transgender Day of}

\section{Remembrance}

DATE CHANGE!

Friday, November 3oth, 8pm

Today we honor and remember everyone that has lost their lives due to hate crimes. Help spread the word that hate is not welcome here and that everyone, regardless, of their identity is welcome in our community. 